\title{
Corporate social responsibility in state entrepreneurship
}

\author{
Tatyana Romaschenko ${ }^{1}$, and Irina Gersonskaya ${ }^{2}$ \\ ${ }^{1}$ Voronezh State University, Kholzunova Str., building 5A, 42 V., 394068 Voronezh, Russia \\ ${ }^{2}$ Russian Presidential Academy of National Economy and Public Administration, Lipetsk branch, 3, \\ Internacionalnaja St., 398050 Lipetsk, Russia
}

\begin{abstract}
This paper examines aspects of corporate social responsibility that is the key element of effective corporate management strategy, including different social and economic programs that contribute to an increase in the level of business activity of the company and strengthening its relationship with society. The authors consider corporate social responsibility in Russian companies, and primarily the public companies. The authors carry out the comparative analysis of the practice of nonfinancial reporting in Russia and abroad, being fundamental for establishing the company's contribution to social development. The authors also analyze the dynamics of the corporate social responsibility indices of Russian companies, including public companies. The study found that Russian companies are at the initial stage of corporate social responsibility development, and non-financial statements are published only by the largest private companies and state corporations. This process does not involve small and medium-sized businesses, as well as small companies with state or municipal ownership. Such circumstance significantly complicates the assessment of the level of corporate social responsibility in Russia, including the state entrepreneurship sector.
\end{abstract}

\section{Introduction}

In modern conditions, the corporate social responsibility (hereinafter referred to as "The CSR") has become a global trend, since dynamic social and economic development, "... the formation of a stable society that guarantees a decent level and quality of life for the population ..." (Kanunnikov, 2017, p. 152), all-round development of human capital assets and the public welfare level growth is very complicated to provide only by the state. Therefore, the government, on the one hand, encourages, and sometimes even forces, the private business to implement a wide variety of social and environmental programs. But, on the other hand, the taking of such measures brings a positive result not only for the society, but also for the business itself that has a real opportunity to impact the external environment in the process of achieving its goals. These circumstances lead to the fact that the activities of business structures are becoming more socially-oriented and responsible before the society, and the corporate social responsibility has become important for determining the business activity of the company... "... and became associated with broader organizational goals such as reputation and stakeholder management” (Lee, 2008, p. 55). 
Socially responsible entrepreneurs organize their business processes in such way as to receive not only the maximum possible profit in the interests of company owners, but also to contribute to regional development by implementing environmental measures, investing in public facilities, extension the experience in introducing social innovations, conducting charitable activities, etc. In corporate social responsibility, the special role is assigned to a person, improving his/her education level, providing him/her additional social preferences, etc., since "... human capital assets are an important factor of economic development ..." (Kosarev, Pavlov, Kaukin, 2019, p. 132) on both separate business unit level and the society in general.

\section{Materials and Methods}

The methodological basis of the study is the corporate social responsibility concepts that is characterized by "...the economic contribution of companies to society" (Farcane and Bureana, 2015, c. 32) and reveals social and economic relations in the context of certain territory sustainable development, arising in the process of interaction between the state, the business sector and the society. The term "corporate social responsibility" is still in popular use, even though competing, complementary and overlapping concepts such as corporate citizenship, business ethics, stakeholder management and sustainability are all vying to become the most accepted and widespread descriptor of the field (Carroll and Shabanac, 2010, p. 86).

The information base of the study are the indices for the corporate social responsibility assessment, calculated by the Russian Union of Industrialists and Entrepreneurs, as well as its ratings for the largest Russian corporations and companies, including companies with state participation. In the process of research, we used general scientific methods of cognition of objective reality, systemic study of social and economic processes and phenomena, methods of structural and logical research and comparison techniques. The sources for substantiating the provisions and conclusions in our study were the works of foreign scientists (A.B. Carroll, K.M. Shabana, N. Farcane, E. Bureana, A. Michaels, D. Ross, C.A. Tilt, W. Visser, etc.) and Russian scientists (E. Gontmakher, N.R. Kelchevskaya, I.M. Chernenko, E.V. Popova, E.D. Kopytova, M.E. Kuznets, etc.) in the sphere of corporate social responsibility development.

\section{Results and Discussion}

CSR has been in longer term use as an explicit framework to better understand the business and society relationship (Carroll, 2015, p. 90). The corporate social responsibility is one of the key parameters for assessing efficiency not only in private business, but also in public entrepreneurship, since under modern conditions of development, the business community is required to increase the threshold of public responsibility aimed at the comprehensive development of human capital assets and the direct participation in solving urgent social and economic issues that will support sustainable inclusive (socially-oriented) economic growth and will contribute to a public welfare level increase in general.

Ultimately, the purpose of business is to serve society, through the provision of safe, highquality products and services that enhance our wellbeing, without eroding our ecological and community life-support systems (Visser, 2011, p. 20). Therefore, the corporate social responsibility lies not only in the observance of labour legislation by state-owned companies, the organization of safe working conditions and advanced training of employees, the stability of wages, the provision of material assistance and the provision of additional social guarantees to their employees, but also the certain contribution of business units to social development, for example, improving the quality of goods and consumer responsibility for 
the manufactured product, carrying out environmental events, introducing social innovations and conducting social entrepreneurship, organizing charitable activities, interacting with government and local authorities in the process of solving social problems, developing public infrastructure facilities, etc. Some public and private entities adopt CSR principles as a core part of their business to avoid the reputational damage that can occur when companies fail to protect the interests of people and ecosystems affected by their operations (Ross, 2017, p. 2)

The main indicators characterizing the level of corporate social responsibility in state entrepreneurship are reflected in non-financial statements, which are the most important tool for forming the comprehensive characteristic of the economic activity of any company. The information presented in them is of public importance and is much broader than the data of the mandatory financial statements of Russian business units. The non-financing reporting “....is a major component of companies' corporate disclosure...considered to mirror companies' CSR performance as a response to increasing stakeholder requirements and legitimate business operations" (Michaels and Grüning, 2018, p. 10). For this reason, such reports include not only the economic parameters and financial performance of companies, but also the quality of the corporate governance system, observance of ethical standards, individual rights and freedoms, the provisions of corporate social policy, as well as the most important socio-environmental indicators reflecting their implementation. public initiatives. Such reporting "... reflects the basic principles and tools of CSR that companies use to improve the social efficiency, which is why the information contained in the statements allows us to judge the level of social responsibility of companies and the CSR management technologies applied in practice" (Kelchevskaya, Chernenko, Popova, 2017 , p. 158). Therefore, on the basis of non-financial reporting data, the performance of public activities is assessed and the contribution of the state company to the general social development of a certain territory is established. Figure 1 shows the number of companies in different countries of the world that publish non-financial statements.

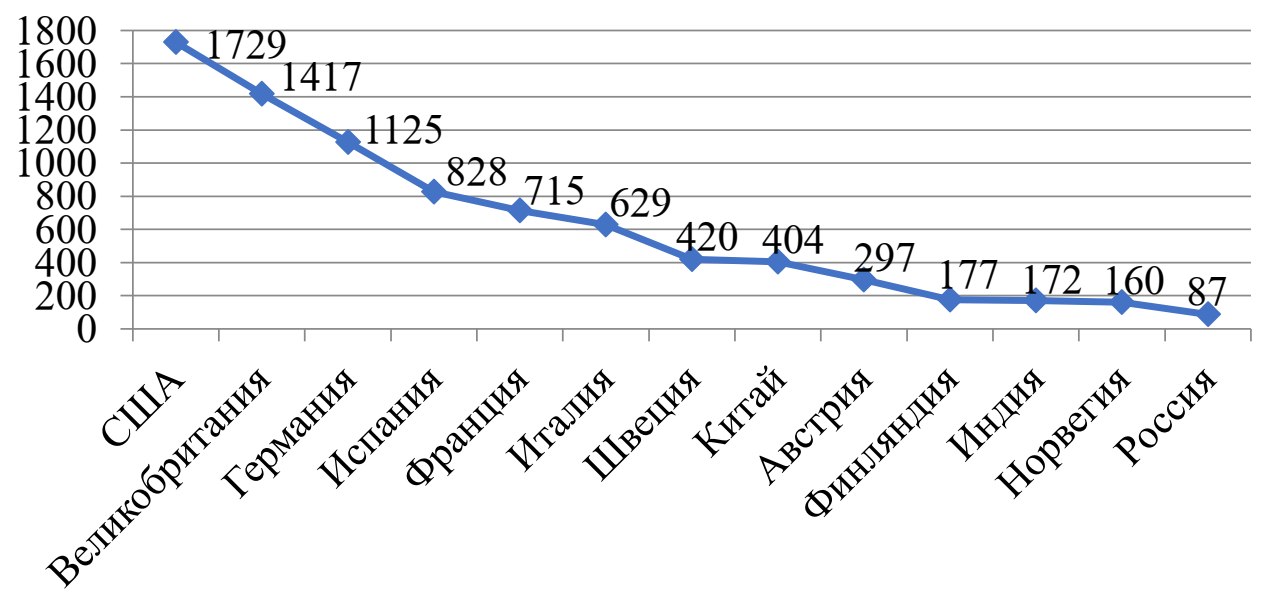

Fig. 1. Number of companies publishing non-financial statements for 2018 by different countries (compiled by authors based on the analytic overview data (Non-financing reporting ..., 2019, p. 47)

Where: США - USA; Великобритания - Great Britain; Германия - Germany; Испания - Spain; Франция - France; Италия - Italy; Швеция - Sweden; Китай - China; Австрия - Austria; Финляндия - Finland; Индия - India; Норвегия - Norway; Россия - Russia.

The data shown in Figure 1 reflects the top three countries in terms of the publication of non-financial reporting - USA, Great Britain and Germany. Generally, economically developed countries and some developing countries, such as China and India, are serious 
about the quality of preparation of non-financial reporting, as well as assessing the corporate social responsibility level. Socially responsible companies in the global community “... have expansive CSR programs, most of which include environmental or climate changed-related initiatives" (Bianco, 2020, p. 11). While Russian companies are only at the initial stage of developing the practice of drawing up such reports. However, in Russia, "non-financial reporting is becoming increasingly important every year. Some state-owned companies ... are obliged to publish non-financial statements ... and the most advanced companies have been disclosed ... reports confirming the company's contribution to sustainable development for a while" (Kuznetsov, 2015, p. 206).

Non-financial statements are mainly formed and published only by the largest of them, operating in the oil and gas sector of the national economy, extraction and processing of minerals, the energy complex, mining and metallurgy, rail transport, air traffic, etc. Among state corporations and companies that provide non-financial reporting are: PJSC "Gazprom", JSC "Zarubezhneft", PJSC "Transneft", PJSC "RusHydro", SC "Rosatom", JSC "Rosenergoatom", PJSC "Rosseti", PJSC "Severstal", PJSC "ALROSA", JSC "Atomredmetzoloto", PJSC "Rostelecom", Aeroflot Group, JSC "Russian Railways" and some others. Some of them are directly in federal ownership, while others operate on the principles of public-private partnership. At the same time, state-owned companies of the regional level and municipal enterprises have not yet realized the full importance of corporate social responsibility, and, as a rule, do not prepare the non-financial reporting, the provision of which is currently not mandatory for many business units. Therefore, at the present stage of development, it is rather difficult to assess the level of corporate social responsibility in Russia, including the state entrepreneurship sector.

However, in Russia, the number of companies, including state-owned companies, that provide non-financial reporting is increasing every year. Both the composition of nonfinancial statements and the list of disclosed parameters are expanding. Currently, the consolidated non-financial statement of business unit may include parameters of sustainable development, environmental and social indicators. Many Russian companies began to prepare integrated and sectoral reports reflecting activities in a particular area of the national economy. But the total number of Russian companies that generate and publish non-financial reporting is still very small, and the practice of corporate social responsibility in Russia lags significantly behind global trends and has not yet found wide public application, and “...in the Russian business environment, the understanding of this category is only beginning to emerge; the related research pays insufficient attention to the study of specific forms, methods and tools contributing to enhancing the role of economic entities in regional development" (Kopytova, 2017, p. 255). Provided that the methodology for corporate social responsibility performance assessment for Russian companies, including state-owned companies, has not been developed by the domestic economic theory and it fails to have the common methodology.

The Russian Union of Industrialists and Entrepreneurs has developed such indices as "Responsibility and Openness" and "Sustainable Development Vector", which in fact are the only domestic tool for assessing the corporate social responsibility level. These indices characterize the performance of private and state Russian companies in the field of corporate social responsibility, business openness and sustainable social and economic development, as well as their impact on natural resources and society, considering economic and social and environmental aspects.

The "Responsibility and Openness" characterizes the quality and degree of information disclosure in non-financial reporting of companies, including state-owned companies, and reflects the level of company public utility and the degree of its openness to society, as well as the overall impact of the company on the social and ecological environment and the human environment. This index is calculated on the basis of several sub-indicators characterizing 
the quality of corporate governance, the development of labour relations and human capital assets, the observance of human rights and freedoms, the implementation of environmental measures and social activities. In general, the Responsibility and Openness Index “... characterizes the real situation with the disclosure of corporate information on CSR in relation to the" ideal "one: the calculated level of disclosure is related to the highest ... the information disclosure index (It) is calculated by the following formula:

$$
I t=\frac{e}{E},
$$

Where: $\mathrm{e}-$ total points calculated for the whole sample,

$\mathrm{E}=$ maximum possible number of points $(\mathrm{E}=\mathrm{xmn}$, where $\mathrm{x}-$ maximum possible point for indicator; $\mathrm{m}$ - number of indicators; $\mathrm{n}$ - number of companies)... "a set of index indicators ... reflects the economic, social and environmental dimensions of corporate social responsibility ... the quality of CSR management and corporate governance issues" (Responsible Business Practice ..., 2017, p. 58).

The "Sustainable Development Vector" reflects the efficiency of companies' activities in the field of corporate social responsibility since it characterizes the dynamic change in the main social and economic and environmental indicators. The calculation of this index also includes several sub-indicators reflecting the labour movement, the safety of working conditions and occupational traumatism, the level of wages and the provision of social guarantees for employees, the development of training systems for advanced training, disposal of production waste, the efficiency of water and energy use, the degree of atmospheric pollution, the engagement in public investments. The "Sustainable Development Vector" index characterizes the level of company production processes' influence on the environment and the provided public benefit. It " ... is based on the ratio of positive and negative "signals" that indicate the direction of changes in the array of reporting data ...:

$$
I v=\frac{Q}{M N},
$$

Where: $\mathrm{Q}$ - sum of signal values, $\mathrm{M}$ - number of signals, $\mathrm{N}$ - number of companies in sample". (Responsible Business Practice..., 2017, p. 63).

Thus, based on the "Sustainable Development Vector" Index, it is possible to determine the actual contribution of any company, including public companies, to the society development. This indicator is calculated on the basis of non-financial reporting data of private and public companies, which showed the best results in the "Responsibility and Transparency" Index. Such companies provide data to assess the degree of their impact on society and the corporate social responsibility effectiveness, namely, safe working conditions and productivity, employee health and social investments, the rational use of production resources, environmental situation, etc.

Different political, social, cultural and economic environments impact on the both the development of, and reporting of, CSR activities and consequently impact on the value of these activities to benefit society and the natural environment (Tilt, 2016, p. 7). Therefore, starting from 2014, the Russian Union of Industrialists and Entrepreneurs, on the basis of non-financial reporting information provided by private and public Russian companies, has been calculating indices characterizing the effectiveness of corporate social responsibility. Figure 2 shows the average values of "Responsibility and Openness" and "Sustainable Development Vector" indices. 


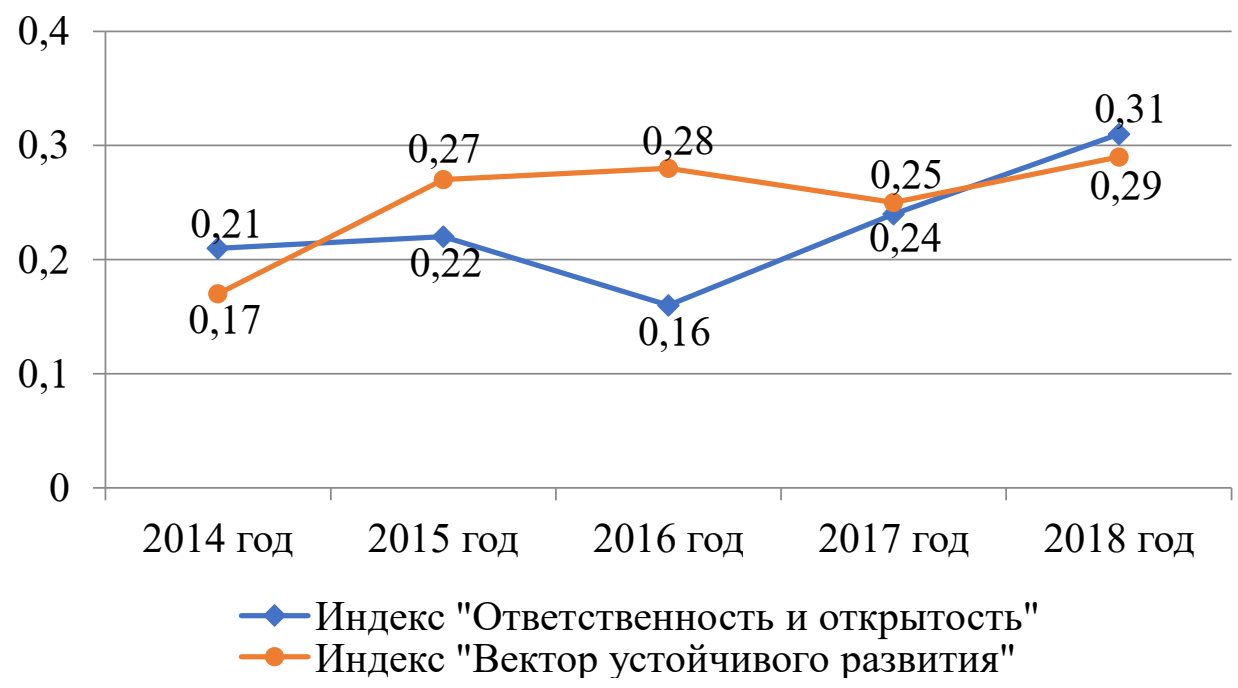

Fig. 2. The average corporate social responsibility index values in Russia in 2014-2018 (compiled by authors based on the analytic overview data (Non-financing reporting ..., 2019, p. 58,63, Responsible Business Practice ..., 2017, p. 58, 62)

Where: Индекс «Ответственность и открытость» - «Responsibility and Openness» Index; Индекс «Вектор устойчивого развития» - «Sustainable Development Vector» Index

The data shown in Figure 2 characterize the discontinuities of the average index values. But in general, in 2018, both indicators have a value that significantly exceeds the level of 2014.

According to the "Responsibility and Transparency" Index, in 2016 there was a sharp decrease in the average value to 0.16 , but in 2017-2018 its significant growth was noticeable. The indicators that form the basis for this index calculation include economic, economic and social aspects (for personnel), as well as the social investment, the corporate social responsibility and the sustainable development management. The average indicator value is much lower than the values of leading companies' individual indicators. The leaders in the "Responsibility and Openness Index", according to the Russian Union of Industrialists and Entrepreneurs rating, are private and public companies included in groups A and B, formed according to the values of their individual indices. At the same time, among state-owned companies in Group A, there are "... individual index values: 0.75 and above... "ALROSA", "Gazprom",... "Rostelecom"... Group B: individual index values: 0.55 and above... “Aeroflot”, "Zarubezhneft" ... "Inter RAO” ... "Russian Railways", "Rosatom”, "Rosseti” ... "RusHydro" ... "(Non-financial reporting ..., 2019, p. 59).

According to the Sustainable Development Vector index, prior to 2016, there was an increase to 0.28 , in 2017 it decreased to 0.25 , but in 2018 it increased to 0.29 . The indicators that form the basis for this index calculation include labour productivity, social and environmental aspects, social investments. In 2018, the leaders of the "Sustainable Development Vector" Index were public “... companies that showed positive values of the individual index "ALROSA", "Gazprom"..." Inter RAO"... "Russian Railways", "Rosatom"... "Rostelecom", "RusHydro"... "Transneft" (Non-financial reporting ..., 2019, p. 64).

The provided data indicate that the leaders in corporate social responsibility include many state corporations and large companies with a mixed form of ownership, operating on the principles of public-private partnerships. However, state and municipal companies with smaller scale in terms of their activity have not yet generate non-financial reporting. Such 
companies have not fully realized the importance of corporate social responsibility for the comprehensive development of human capital assets, provision of conditions for creating economic and social and ecological stability in the country, sustainable inclusive (socialoriented) economic growth, reducing the social tension and increasing the public welfare level.

\section{Conclusion}

At the present stage, the corporate social responsibility is focused on the human capital assets development and the public welfare level increase. Such responsibility acts as a modern mechanism for the effective resolution of conflicts that periodically arise in labour collectives, aimed at achieving social and economic development and the social stability. The corporate social responsibility involves not only the relationship between the functioning of competitive economy and the sustainable social development, but also with respect for nature, the development of human capital assets and the improvement of the quality of life. Therefore, non-financial statements, reflecting the social responsibility entrepreneurship level, are being actively introduced into corporate management practice and "the future of CSR will also have to take into consideration the latest technological advances and their role as part of new business frameworks and strategies" (Agudelo, Jóhannsdóttir, Davídsdóttir, 2019, p. 20).

The corporate social responsibility is characteristic not only for the private sector, but also for state entrepreneurship structures. In Russia, the largest state corporations are actively developing and implementing strategies of social nature, being also leaders in increasing the corporate social responsibility level. However, at the present stage of development, such responsibility is characteristic only for large business units, both in the entrepreneurial and public sector of the economy. Small and medium-sized businesses, as well as small companies with state or municipal ownership, practically do not use corporate social responsibility standards, which has a negative impact on the process of social development. In such conditions, “.... a scenario becomes very likely in which ... the main social parameters will slowly but steadily deteriorate" (Gontmakher, 2017, p. 16). Therefore, in Russia there is a task of widespread extension of best practices and implementation of corporate social responsibility strategies in business structures, since the international practice has long proven the effectiveness of business social responsibility for society.

\section{References}

1. L. Agudelo, L. Jóhannsdóttir, B.A. Davídsdóttir, International Journal of Corporate Social Responsibility, 4 (2019)

2. G.B. Bianco, International Journal of Corporate Social Responsibility, 5 (2020)

3. A.B. Carroll, Organizational Dynamics , 44, 87 (2015)

4. A.B. Carroll, K.M. Shabana, International Journal of Management Reviews, 12(1), 85 (2010)

5. N. Farcane, E. Bureana, Annales Universitatis Apulensis Series Oeconomica, 17(2), 31 (2015)

6. E. Gontmakher, Global Economi and International Relations, 61(3), 15 (2017)

7. A.A. Kanunnikov, Modern Europe, 1(73), 152 (2017)

8. N.R. Kelchevskaya, I.M. Chernenko, E.V. Popova, Region Economy, 13(1), 157 (2017) 
9. E.D. Kopytova, Economic and Social Changes: Facts, Trends, Forecast, 10(1), 254 (2017)

10. V. Kosarev, P. Pavlov, A. Kaukin, Economic policy, 14(5), 124 (2019)

11. M.E. Kuznetsov, Journal of the New Economic Association, 1(25), 204 (2015)

12. M.-D. P. Lee, International Journal of Management Reviews, 10(1), 53 (2008)

13. A. Michaels, M. Grüning, International Journal of Corporate Social Responsibility, 3 (2018)

14. L.V. Feoktistova, E.N. Alenichava, G.A. Kopylova, M.N. Ozeranskaya, D.R. Purtova, N.V. Khonyakova, Non-financial reporting in Russia and worldwide: Sustainable Development Goals Case Study. Analytical review of corporate on-financing statements: 2017-2018, 104 (2019)

15. L.V. Feoktistova, E.N. Alenichava, G.A. Kopylova, M.N. Ozeranskaya, D.R. Purtova, N.V. Khonyakova, Responsible Business Practice in terms of reporting: present and future. Analytical review of corporate on-financing statements: 2015-2016, 136 (2017)

16. D. Ross, International Journal of Corporate Social Responsibility, 2 (2017)

17. C.A. Tilt, International Journal of Corporate Social Responsibility, 1 (2016)

18. W. Visser, Journal of Business Systems, Governance and Ethics, 5(3), 7 (2011) 